Pamiętnik Literacki 2018, 3, s. 205-216

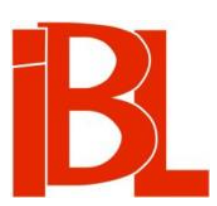

Ostatni tekst autorstwa Janusza Korczaka opublikowany za jego życia

Agnieszka Witkowska-Krych 
Pamiętnik Literacki CIX, 2018, z. 3, PL ISSN 0031-0514

DOI: $10.18318 / \mathrm{pl} .2018 .3 .13$

AGNIESZKA WITKOWSKA-KRYCH Uniwersytet Warszawski

\section{OSTATNI TEKST AUTORSTWA JANUSZA KORCZAKA OPUBLIKOWANY ZA JEGO ŻYCIA}

Uważa się powszechnie, że ostatnim tekstem Janusza Korczaka, wydanym drukiem jeszcze za jego życia, jest Pedagogika żartobliwa, która ukazała się nakładem Towarzystwa Wydawniczego w Warszawie na przełomie maja i czerwca 1939, zatem niedługo przed wybuchem drugiej wojny światowej. Książka ta była w zasadzie tożsama z cyklem "gadaninek” radiowych Korczaka noszącym tytuł Moje wakacje. Zbiór ten, anonsowany w czasopiśmie radiowym „Antena” jako „powieść Starego Doktora dla dzieci”, nadawany był przez Polskie Radio od 4 VII do 18 VIII 1938 w 13 odcinkach długości po 15 minut, w poniedziałki i czwartki o godzinie 15:15¹. Pomysł tych audycji zrodził się najprawdopodobniej w latach trzydziestych podczas letnich pobytów Korczaka w nadbużańskim majątku Mężenin, w którym spotykali się wolnomularze należący do kontemplacyjnej loży „Le Droit Humain” oraz członkowie Polskiego Towarzystwa Teozoficznego. Przyjeżdżali tam również ludzie całkiem nie związani $z$ masonerią czy teozofią, ot, po prostu znajomi znajomych. Szczególnie dobrze - jak pisze Hanna Rudniańska we wspomnieniowej ksiażce czuły się w Mężeninie dzieci, dla których organizowano ogniska i inne atrakcje ${ }^{2}$. Niektórzy z młodych bywalców letniska stali się dla Korczaka prototypami bohaterów Pedagogiki żartobliwej.

Cykl „gadaninek”, który ostatecznie złożył się na tę książkę, zapowiadano jako „powieść mówioną". Korczak sięgną po formę dość nową, plasującą się między typowym słuchowiskiem a odczytywanym tekstem literackim. Tematem miały być scenki rodzajowe dotyczące życia codziennego i kulturalnego zachowania się. $P e^{-}$ dagogika żartobliwa stanowiła dopełnienie wcześniejszych utworów Korczaka: Prawidta życia (o podtytule Pedagogika dla młodzieży $i$ dorosłych) oraz Prawo dziecka do szacunku. Te trzy teksty - według Elżbiety Cichy - spajała idea mówiąca, że dziecko jest człowiekiem nie mniej wartościowym niż dorosły ${ }^{3}$, choć - jak dodawał Korczak - o nieco skromniejszym bagażu doświadczeń. W przypadku

1 Zob. E. Ci c hy, „Pedagogika żartobliwa”. Geneza utworu. W: J. Ko r c za k, Senat szaleńców. Proza poetycka. - Utwory radiowe. Red. nauk. H. Kirchne r. Oprac. E. Cichy. Uwagi E. Cichy, H. Kirchner. Przypisy M. Prussak. Przekł. filologiczny E. Świderska. Warszawa 1994, s. 365. Dzieła. T. 10.

2 H. Rudniańs ka, Korczak, Tokarzewski imy. Wspomnienia i rozmowa z K. Sh m er u k. Kraków 2005.

$3 \quad$ Cichy, op. cit., s. 369. 
Pedagogiki żartobliwej mamy jednak do czynienia z tekstem szczególnym, łączącym literacką narrację w postaci monologu z dialogiem i odgrywaniem epizodów „Z życia”. Pokrewieństwo zastosowanej tutaj formy wiąże to dzieło $z$ innymi krótkimi formami literackimi, po jakie Korczak sięgał uprzednio, np. przy pisaniu artykułów do „Małego Przeglądu”, czy też z wczesnymi utworami dotyczącymi wydarzeń, które miały miejsce na koloniach letnich dla żydowskich i polskich chłopców (odpowiednio w Michałówce i Wilhelmówce), gdzie Korczak pracował jako wychowawca w latach 1907, 1908 i $1910^{5}$.

Nie jest zatem zaskakujące, że Pedagogice żartobliwej nadano szczególne znaczenie, tym bardziej że opublikowano ją tuż przed wybuchem wojny, która przyniosła Korczakowi śmierć. Tytuł z ówczesnej (ale też i z dzisiejszej) perspektywy musiał intrygować - lat trzydziestych XX wieku w Europie nie można bowiem uznać za okres, w którym chciałoby się niefrasobliwie żartować. Kryzys ekonomiczny końca lat dwudziestych oraz wzrost nastrojów antysemickich w Europie nie nastrajały do śmiechu. Sam Korczak w retrospektywnej części Pamiętnika, pisanego w warszawskim getcie od maja do sierpnia 1942, nazywa ten czas w sposób nie budzący wątpliwości:

Podłe, haniebne lata - rozkładowe, nikczemne. Przedwojenne, kłamliwe, zakłamane. - Przeklęte. Nie chciało się żyć.

Błoto. Cuchnace błoto ${ }^{6}$.

Co więcej, w związku z tym, iż nie zachowało się nagranie żadnej z Korczakowskich audycji radiowych, tekst Pedagogiki żartobliwej jest dziś świadectwem ich treści. Jej subtelny optymizm sprawia też, że - niejako podświadomie - chciałoby się traktować ją jako podsumowujący literacki dorobek życia, ostatni utwór z rozmysłem podany przez autora do druku.

Wbrew - być może - zdroworozsądkowemu przekonaniu okazuje się jednak, że ksiażka ta nie jest ostatnim tekstem Korczaka opublikowanym za jego życia. Można uznać, że to ostatnie jego dzieło literackie, które ujrzało światło dzienne w formie drukowanej przed wybuchem drugiej wojny światowej, aczkolwiek nie ostatni oficjalnie wydany tekst. Jeśli zaliczymy do spuścizny pisarskiej autora nie tylko utwory stricte literackie, ale także te, które nie maja jednoznacznie takiego charakteru, to tym bardziej przeświadczenie na temat „ostatniości” będzie trzeba zrewidować. Chciałabym zatem przyjąć, że spuścizna Korczaka obejmuje zarówno teksty literackie, jak i wszystkie pozostałe, które wyszły spod jego pióra. Wśród nich będą zatem i beletrystyka pisana $z$ przeznaczeniem dla dzieci czy dorosłych, i artykuły publicystyczne, i tzw. literatura dokumentu osobistego, czyli m.in. prywatne listy oraz wzmiankowany Pamiętnik.

J. Korczak, Prawidła życia. - Publicystyka dla dzieci. Red. nauk. A. Lewin. Oprac. tekstów, uwagi o tekstach J. Bartnicka. Genezy utworów i przypisy J. Papuzińska, A. Wern i k, przy współpr. M. Ci e si els ki ej. Przekł. filologiczny tekstów hebr. E. Świ d e rs ki. Oprac. literackie H. Kirchner. Warszawa 2007. Dzieła. T. 11.

5 J. Kor cza k, Mośki, Joski i Srule. - Józki, Jaśki i Franki. Red. nauk. A. Le wi n. Oprac. tekstów, geneza utworów, uwagi o tekstach, przypisy M. Ciesi els ka. Warszawa 1997. Dzieła. T. 5.

6 J. Korczak, Pamiętnik i inne pisma z getta. Przypisy M. Ciesielska. Posł. J. Le ociak. Warszawa 2012, s. 98. 
Określając w ten sposób pole badań, muszę zatem stwierdzić, że ostatnim tekstem Korczaka, jaki został wydany drukiem za jego życia, jest nie Pedagogika żartobliwa, ale jego list, który ukazał się w styczniu 1942 na łamach „Gazety Żydowskiej”, niemieckiej „gadzinówki” przeznaczonej dla mieszkańców gett w Generalnym Gubernatorstwie ${ }^{7}$. Docierała ona do warszawskiej dzielnicy żydowskiej regularnie, choć nie uchodziła za wiarygodne źródło rzetelnych informacji i traktowana była jak tuba propagandowa okupanta. Jerzy Jurandot po latach pisał o niej:

Wiadomości politycznych starali się Niemcy do getta zupełnie nie dopuszczać. Nawet niemieckie gazety były zakazane, nawet warszawski „szmatławiec" $\mathrm{z}$ drugiej strony murów. Przychodziła jedynie wydawana w Krakowie obrzydliwa „Gazeta Żydowska”, zawierająca sześć wierszy oficjalnego komunikatu i cztery szpalty uniesień nad życiem Żydów pod panowaniem „Herrenvolku”.

\section{Henryk Bryskier podaje zaś istotną informację na temat jej poczytności:}

„Gazeta Żydowska” mimo wyłączności debitu nie była popularną i miała znikomą liczbę prenumeratorów, a pojedynczo sprzedawane egzemplarze przez kolporterów nie wróżyły jej rozwoju ${ }^{10}$.

Faktem jednak jest, że obok przekłamanych danych, dotyczących działań militarnych, „Gazeta Żydowska” zawierała również drobne, szczegółowe, nie obciążone politycznie informacje, mówiące o codzienności gett Generalnego Gubernatorstwa, co pozwala dziś badaczom - przy zachowaniu koniecznej dozy ostrożności i krytycyzmu - zbliżyć się do tamtej rzeczywistości.

Nazwisko Korczaka (nigdy Henryka Goldszmita) pojawia się na łamach „Gazety Żydowskiej” prawie 40 razy, zwykle przy okazji ogólnych wzmianek na temat prowadzonego przez niego Domu Sierot, musiał przenieść się do getta w listopadzie 1940, na ul. Chłodna 33, do budynku dawnego gimnazjum kupieckiego dla chłopców ${ }^{11}$, a później - w związku ze zmianami granic dzielnicy żydowskiej - przeniósł się raz jeszcze, pod adres: ul. Sienna 16 / Śliska 9, do gmachu Towarzystwa Pracowników Handlowych i Przemysłowych. Nie była to zresztą jedyna instytucja całkowitej opieki nad dzieckiem żydowskim, która spotkał wtedy taki los ${ }^{12}$.

Opierając się nie tylko na wiedzy ogólnej, ale przede wszystkim na zachowanych materiałach, zgromadzonych głównie w Archiwum Żydowskiego Instytutu Historycznego oraz w Muzeum Bojowników Gett w Izraelu, da się wywnioskować, że sytuacja materialna Domu Sierot, mimo różnorodnych prób zdobywania dodatkowych środków, z roku na rok pogarszała się. Szacuje się, że od września 1939 do 5 VIII 1942, czyli do dnia deportacji do Treblinki, liczba dzieci wzrosła od 107

Więcej o „Gazecie Żydowskiej” zob. M. J a n c zew s ka, Gazeta Żydowska (1940-1942). W zb.: Studia z dziejów trójjęzycznej prasy żydowskiej na ziemiach polskich (XIX-XX wiek). Red. J. Nalewajk o-Kulikov. Współpr. G. P. Bą bi a k, A. J. Ci és lik owa. Warszawa 2012, s. 167-180. Mowa o „Nowym Kurierze Warszawskim”, zwanym przez warszawiaków „szmatą” lub „kurwarem”.

9 J. Ju ran d ot, Miasto skazanych. W: J. J u ra n d o t, Miasto skazanych. 2 lata w warszawskim getcie. - S. Grodzień ska, Dziecigetta. Oprac. krytyczne P. Szapiro, A. Arnold. Warszawa 2014, s. 120.

10 H. B ry s ki e r, Żydzi pod swastyka, czyli getto $w$ Warszawie $w$ XX wieku. Warszawa 2006, s. 97.

11 Chodzi o Szkołę Handlową im. Marii i Józefa Roesslerów.

12 Przymusowe przeprowadzki instytucji opiekuńczych w getcie zaświadczone sa w dokumentach Żydowskiej Samopomocy Społecznej, przechowywanych w Archiwum Żydowskiego Instytutu Historycznego (sygn. 211/12), oraz w „Gazecie Żydowskiej” (nr 47, z 31 XII 1940, s. 3). 
(w założeniu dla tylu wychowanków zaprojektowany był własny budynek Domu Sierot, mieszczący się przy ul. Krochmalnej 92) do około 200. Co więcej, organizacja pozarządowa subsydiująca placówkę przed wojną, czyli Towarzystwo „Pomoc dla Sierot”, po jej wybuchu działała już tylko w szczątkowej postaci, czego naturalnym efektem było znaczne zmniejszenie wsparcia. Wprawdzie, Dom Sierot (tak jak inne instytucje opieki nad dziećmi) otrzymywał za pośrednictwem Żydowskiej Samopomocy Społecznej ${ }^{13}$ dodatkowe środki, płynace $z$ amerykańskiego Jointu ${ }^{14}$ lub z warszawskiej, gettowej Gminy Żydowskiej (Judenratu), o czym świadczą zachowane dokumenty administracyjno-księgowe, najczęściej jednak były to zasiłki nie wystarczające. Zarząd Domu Sierot przy wsparciu Towarzystwa „Pomoc dla Sierot” próbował radzić sobie $z$ sytuacją niedoboru, organizując chociażby koncerty dochodowe, czy to w nowej siedzibie Domu Sierot, czy też np. w lokalu działającego w getcie teatru o nazwie „Melody Palace”, mieszczacego się przy ul. Rymarskiej $12^{15}$. Ostatnim takim wydarzeniem, które mogło mieć właśnie charakter na poły charytatywny, było odegrane przez wychowanków przedstawienie Poczta autorstwa hinduskiego noblisty Rabindranatha Tagorego, 18 VII 1942 pokazane po raz ostatni $^{16}$.

Zachowane wspomnienia ${ }^{17}$ mówią również o tym, że sam Korczak próbował zdobywać fundusze i inne środki, które miały być przeznaczone na utrzymanie zwiększającej się liczby podopiecznych. Jest bardzo prawdopodobne, iż korzysta-

13 Żydowska Samopomoc Społeczna - organizacja dobrowolnej opieki społecznej nad ludnościa żydowską w Generalnej Guberni, powołana przez władze okupacyjne w maju 1940, odpowiednik polskiej Rady Głównej Opiekuńczej.

14 Joint, tj. American Jewish Joint Distribution Committee - organizacja charytatywna założona w Stanach Zjednoczonych w listopadzie 1914, pod wpływem wiadomości o tragicznej sytuacji Żydów w ogarniętej wojną Europie. W Polsce początkowo Joint prowadził akcję pomocy ofiarom wojny; od 1920 roku podjął długofalowe działanie zmierzające do przekształcenia struktury społecznej i zawodowej ludności żydowskiej; w latach 1939-1945 roztaczał opiekę nad żydowskimi uchodźcami i przesiedleńcami. W getcie warszawskim pod jego auspicjami zorganizowano sieć kuchni ludowych, utrzymywano sierocińce, udzielano pomocy inteligencji, zbierano odzież dla biednych i uciekinierów z małych miasteczek. Przedstawiciele Jointu zaciagali na owe przedsięwzięcia pożyczki u osób prywatnych, obiecując ich zwrot po zakończeniu wojny.

15 Ogłoszenie z „Gazety Żydowskiej”, które ukazało się w nrze z 23 V 1941, brzmiało: „W niedzielę, dnia 25 bm., o godz. 12.15 odbędzie się w salonach "Melody Palace», Rymarska 12, wielki poranek artystyczny, w którym wezmą udział znani artyści warszawscy. Impreza ta urządzona została staraniem znanych działaczy w dzielnicy, pp. M. Kona i Z. Hellera, którzy całkowity dochód z poranku przeznaczyli na utrzymanie 300 sierot we wzorowym "sierocińcu p. Dr. J. Korczaka" przy ul. Chłodnej 33. Ze względu na cele, którym impreza ta jest poświęcona, zasługuje ona na szczególne poparcie. Bilety są do nabycia w Domu Handlowym Kon i Heller, Leszno 14, oraz przy kasie w dniu imprezy". Trzeba zaznaczyć, że liczba podopiecznych Korczaka została zawyżona. Warto, być może, zwrócić w tym miejscu uwagę na patronów imprezy, czyli Moryca Kona i Zeliga Hellera, którzy dzięki bliskim kontaktom z Niemcami stali się właścicielami wielu koncesji, m.in. na gettowy tramwaj konny, zwany powszechnie „konhellerka”. Przez społeczność getta uznawani byli za kolaborantów.

16 Zob. A. Wit kow s ka, Między gettem a niebem, czyli o ostatnim przedstawieniu $w$ Domu Sierot Janusza Korczaka. „Kwartalnik Historii Żydów” 2009, nr 3.

17 Zob. szkice Czas zagłady S. Elias bergowej i Na Chłodnej 33 M. Zylberberga (w zb.: Wspomnienia o Januszu Korczaku. Wybór, oprac. L. Bar szc zew s ka, B. Mil ewicz. Warszawa 1981). 
jąc ze swej przedwojennej popularności, dowcipu i siły perswazji, był w tych przedsięwzięciach dość efektywny ${ }^{18}$. Niestety, brak danych, które by to uszczegółowiły.

Nie ulega także wątpliwości, że Dom Sierot kierowany przez Korczaka był w getcie instytucją znaną, nie tylko dzięki dyrektorowi czy też za sprawą jego najbliższej współpracowniczki, działającej w różnych gremiach Stefanii Wilczyńskiej, ale również przez wzgląd na samą renomę zakładu, mającego przed wojną charakter nowatorski i uchodzącego za miejsce, do którego szczególnie warto oddać dziecko potrzebujące wsparcia. Trudno powiedzieć, czy można go nazwać placówką „pokazową", reprezentującą w pełni obraz żydowskiej opieki nad dzieckiem opuszczonym, pewne jest jednak, iż była to instytucja znana w żydowskich i polskich kręgach pedagogicznych, tak przed wojna, jak i w czasie jej trwania. Nic zatem dziwnego, że stała się ona również przedmiotem reportażowego tekstu, który ukazał się w drugiej połowie grudnia 1941 na łamach „Gazety Żydowskiej”. Warto może wspomnieć przy okazji, że publikacji poświęconych różnym instytucjom opieki społecznej było w tym czasopiśmie więcej - część dotyczyła Warszawy, część zaś mówiła o placówkach pozawarszawskich ${ }^{19}$.

Autorką reportażu była Guta Ejzencwajg, wówczas dwudziestokilkuletnia kobieta, współpracująca $z$ pismem już od 1940 roku $^{20}$. Pod koniec 1941 roku zaaranżowane zostało zwiedzanie Domu Sierot, a być może także spotkanie oraz rozmowa z samym Korczakiem. Nie ma chyba potrzeby, by przytaczać w pełnym brzmieniu ów reportaż, dość powiedzieć, że miał on charakter wysoce panegiryczny. Kilka cytatów świadczy o tym dobitnie:

Ręka drży ze wzruszenia, gdy człowiek zabiera się do skreślenia choćby najogólniejszego zarysu tego całego kompleksu, jaki przedstawia Dom Sierot z jego twórcą, duchem, kierownikiem - Januszem Korczakiem.

[...] Doktor Korczak, siedzi ze zmarszczonym czołem i kombinuje..., i wystaje w urzędach, instytucjach, przed drzwiami dyrektorów - bez względu na to, że nazwisko Korczak ma również swoją wagę. Cóż imię? Cóż honor? Kiedy dzieci, jego dzieci czekają... ${ }^{21}$

„Korczak to jak prawdziwy ojciec” - stwierdza jedno z dzieci w chwili jego nieobecności - „który stale o nas pamięta”. Co tydzień je waży, mierzy i bada, i nikt $z$ nas nie pojmuje bólu tego człowieka, gdy przeglądając linię wagi stwierdza, że się [ona] nie podnosi. Co z tego, że p. Korczak opowie dzieciom bajki, że ich pogłaszcze, pocałuje i uśmiechnie się - co z tego, że wywołuje śmiech ich, że oczy im się

Korczak (Pamiętnik $i$ inne pisma z getta, s. 92) notował: „Wizyt nie składam. Chodzę żebrać o pieniądze, produkty, wiadomość, radę, wskazówkę. [...] są one [tj. takie wizyty] ciężką i poniżająca pracą. A trzeba błaznować, bo ludzie nie lubią ponurych twarzy".

W „Gazecie Żydowskiej” (1942, nr 39, z 1 IV, s. 2), można było przeczytać reportaż H. C z e r w ińskie go, dotyczący Głównego Domu Schronienia, który mieścił się w getcie warszawskim przy ul. Dzielnej 39. W nrze 4, z 2 VIII 1940 (s. 6), ukazał się zaś anonimowy artykuł o Zakładzie Wychowawczym Sierot Żydowskich zlokalizowanym przy ul. Dietla w Krakowie.

20 Po raz pierwszy nazwisko G. Ej ze n c wajg pojawia się w nrze 30, z 1 XI 1940, na stronicy 11 , gdzie występuje ona jako tłumaczka hebrajskiego tekstu Misterium soboty autorstwa F. Roz encweiga.

21 O tym, że Korczak był zaborczy w kwestii zdobywania środków dla „swoich” dzieci, pisze chociażby Z. Szy mańs ka (Nie uległ skamieniałym sercom. W zb.: Wspomnienia o Januszu Korczaku, s. 324). 
iskrzą z zadowolenia - kiedy on sam wie i czuje braki w ich małych organizmach, i nic im poradzić nie może.

Korczak nie ustaje w pracy, nie wpada w rozpacz, ale martwi się. I głębokie zmarszczki na jego wysokim czole pogłębiają się.

kto zwątpił w dobroć i bezinteresowność ludzką, czyja dusza tęskni za prawdziwym przeżyciem, głębokim jak sam ból, jak sama czysta radość tworzenia, niech pójdzie i przyjrzy się oczom i twarzy Korczaka.

Korczak to jedna z najpopularniejszych postaci Warszawy kulturalnej, a też całego kraju. Jego dziesiątki powieści dla dzieci i o dzieciach, jego dzieła pedagogiczne, jego referaty, odczyty, przemówienia - to przecież prawdziwe biesiady duchowe, które niejednemu $z$ nas umilały godziny skupienia. Jego Zakład Sierot, słynny na całym świecie, instytucja, która była i pozostanie wzorem i przykładem również jest znany każdemu. A jednak poznać prawdziwą wielkość można, tylko obserwując Korczaka wśród jego dzieci, w jego Zakładzie. (Ostatnio został [on] przeniesiony z ul. Chłodnej na Sienna 16). Dlatego jest on i pozostanie dumą żydowskiej ludności Warszawy; choćby nie wszyscy o tym dziś pamiętali...22

Ejzencwajg kończy swój reportaż wzniośle, nazywając Korczaka geniuszem, od którego należy się uczyć.

Tekst Zakład Sierot Janusza Korczaka miał na celu najprawdopodobniej zwiększenie świadomości mieszkańców getta, zwrócenie ich uwagi na potrzeby dzieci opuszczonych i tym samym zintensyfikowanie wsparcia materialnego sierot, w efekcie jednak stał się dość natrętnym hymnem pochwalnym na cześć Korczaka. Już sam tytuł podkreśla jego pierwszorzędną rolę i odpowiedzialność za instytucję, dalsza treść zaś tylko wzmacnia to wrażenie. Nietrudno się domyślić, że ów parareportaż mógł wzbudzić w Korczaku co najmniej mieszane uczucia. Zgadzając się na wejście „reportera-amatora”, pracującego w gazecie o - delikatnie mówiąc - dość podejrzanym charakterze, do zarządzanej przez siebie placówki w czasie dla niej zdecydowanie nie najłatwiejszym, jej kierownik albo wykazał się daleko idąca ufnością, albo też założył, że tego typu tekst przyniesie Domowi Sierot jakieś wydatne korzyści w postaci dodatkowych środków. $Z$ drugiej jednak strony, Korczak raczej nie życzył sobie, co chyba zrozumiałe, by odmalowany przez Ejzencwajg obraz sugerował czytelnikom, że Dom Sierot miewa się doskonale i że żadna pomoc nie jest mu potrzebna. Nie chciał, by (znane mu skądinąd) plotki dotyczące prowadzonego przezeń zakładu, „uchodzącego [...] za raj, oazę, wyspę szczęśliwości” ${ }^{23}$, utwierdziły się wśród mieszkańców getta. I - co chyba najważniejsze - nie pragną̧, by jego jedynego uczyniono odpowiedzialnym za ten (tak entuzjastycznie tutaj zaprezentowany) sukces organizacyjny. Zdawał sobie również sprawę, że Dom Sierot znajdował się na przełomie 1941 i 1942 roku w sytuacji chyba najgorszej w swojej historii - lokal przy Siennej 16 / Śliskiej 9, do którego przeprowadzili się w październiku 1941, dzielony był z innymi instytucjami ${ }^{24}$, liczba dzieci zwiększyła się,

G. Ej z e n c waj g, Zakład Sierot Janusza Korczaka. „Gazeta Żydowska” 1941, nr 127, z 21 XII, s. 2.

23 J. Korc zak, Multatuli. W zb.: Janusz Korczak $w$ getcie. Nowe źródła. Wstęp, red. nauk. A. Lewi in. Oprac. filologiczne tekstów M. Ziółek. Przypisy M. Ci esiels ka [i in.]. Warszawa 1992, s. 136.

24 Mieściły się tam m.in. kuchnia ludowa dla ubogich mieszkańców getta i kawiarnia Tatiany Epstein, w której grywał Władysław Szpilman. 
a widoki na poprawę warunków wydawały się zdecydowanie nikłe. Zrozumiałe jest zatem, że przedstawienie położenia Domu Sierot wyłącznie w jasnych barwach stanowiłoby nie tylko przekłamanie, ale także czynnik potencjalnie zmniejszajaccy zainteresowanie czytelników dalszym wspieraniem tej instytucji.

Niestety, te prawdopodobne wstępne założenia i plany okazały się zdecydowanie rozbieżne $z$ tym, co wydrukowano na drugiej stronicy „Gazety Żydowskiej” w niedzielę 21 XII 1941. Oczywiście, ciekawe jest również, jaką drogą opublikowany reportaż trafił w ręce Korczaka: czy on sam nabył gazetę, czy też została mu ona przez kogoś dostarczona w akcie dobrej woli. Niewykluczone, że mógł to być rodzaj egzemplarza autorskiego, obiecanego Korczakowi przez dziennikarkę, w zamian za zgodę na jej wejście na teren instytucji. Nie da się tego dziś ustalić, wiadomo jednak, że już 7 I 1942, czyli nieco ponad dwa tygodnie później, w środę, w „Gazecie Żydowskiej” ukazał się list Korczaka bezpośrednio odnoszacy się do tekstu Ejzencwajg. List ten, napisany, być może, od razu po lekturze tekstu Zakład Sierot Janusza Korczaka, w formie uprzejmego, acz stanowczego sprostowania, wskazywałby na fakt, iż przygotowany przez Ejzencwajg materiał nie został autoryzowany. Ciekawe, że tego rodzaju sprostowań w „Gazecie Żydowskiej” praktycznie nie ma - list Korczaka, będący czymś w rodzaju osobistego dementi, to jedyny przykład w historii działalności czasopisma.

Jako że sprostowanie to jest przedmiotem moich rozważań, pozwolę sobie przytoczyć je w całości.

\section{LIST JANUSZA KORCZAKA ${ }^{25}$}

Szanowny Panie Redaktorze!

Dziękuję za życzliwą ocenę pracy Domu Sierot. Ale...

„Miły Platon, bardziej miła prawda”26.

Dom Sierot nie był, nie jest, nie będzie Domem Sierot Korczaka. Za mały, za słaby, za biedny i za głupi [on] na to, by dwie setki bez mała dzieci wybrać, ubrać, zgromadzić - wyżywić, ogrzać - otoczyć opieką i w życie wprowadzić... Tej wielkiej pracy dokonał wysiłek zbiorowy wielu setek ludzi dobrej woli i światłego zrozumienia sprawy dziecka... sieroty. Są wśród nich liczne piękne imiona, są liczni bezimienni... - ich praca, pomoc, rada, doświadczenie budowały materialnie i duchowo wartości tego warsztatu i bogatego przedsiębiorstwa.

Wilczyńska, Pozówna, Korczak (jeśli potrzebne imiona) - to urzędnicy i administratorzy znacznej fortuny.

Zabezpieczeni odnośnie [do] potrzeb osobistego życia - ile umieją, wiedzą i mogą - starają się poprawnie i celowo wypełniać warunki umowy [zawartej] z Zarządem Towarzystwa „Pomoc dla Sierot”, a przez Zarząd ze Społeczeństwem. Na debet i credit Instytucji składają się walory i braki całej dzielnicy żydowskiej, wszystkich jej członków. Zasługą dzieci, ich rodzin, byłych i obecnych wychowańców, zarówno najbliższych, jak i najdalszych sercu i pamięci, jest [to], że Dom Sierot posiadł życzliwość i zaufanie, imię dobre i możność dalszego istnienia.

Nie zajmowałbym czasu, uwagi i papieru sprostowaniem mało ważnej niedokładności, gdyby nieporozumienie nie miało ogólnego znaczenia: mylnie utożsamiamy zakres, technikę, sprawność i wynik pracy z osobą urzędnika, któremu została [ona] powierzona do wykonania.

\section{J. Korczak}

Pierwodruk: „Gazeta Żydowska” 1942, nr 3, z 7 I, s. 2. W publikowanym tu liście uwspółcześniono ortografię i interpunkcję. W nawiasach kwadratowych umieszczono uzupełnienia dodane przez autorkę artykułu. 
PS. - Na cmentarzu w Paryżu jest piękny pomnik z napisem: „Zmarłym. Wszystkim, którzy odeszli, ku pamięci" ${ }^{27}$. - Niezadługo staraniem Patronatu naszego odbędzie się nabożeństwo za dusze zmarłych Przyjaciół i Wychowanków Domu Sierot ${ }^{28}$.

Bezpośrednio pod listem umieszczona jest również dodatkowa informacja (nieustalonego autorstwa), brzmiąca następująco:

Zapraszamy na piękne, pogodne bajki (kukiełki) - które opowie pan Dr JANUSZ KORCZAK w sobotę, dnia 10 stycznia br., o godz. $12 \mathrm{w}$ południe w lokalu DOMU SIEROT, przy ul. ŚLISKIEJ 9. Cena biletu dla dzieci i dorosłych - zł $2^{29}$.

Tytuł został nadany tekstowi najprawdopodobniej przez redaktora „Gazety Żydowskiej”. Wydrukowano go inną czcionką, pogrubionym składem i przede wszystkim wielkimi literami, co - jak sądzę - miało zwrócić nań szczególną uwagę czytających. Nie wiemy jednak, niestety, z czyjej inicjatywy wynikało takie posunięcie. Nie wiemy również, czy opublikowany 7 I list był jedynym materiałem, który przekazano do redakcji „Gazety Żydowskiej” ${ }^{30}$. Mogło mu wszakże towarzyszyć jakieś dodatkowe pismo przewodnie, w którym, w słowach przeznaczonych dla węższego grona, motywowana była konieczność zamieszczenia sprostowania. Niewykluczone także, że sam autor listu pofatygował się osobiście do redakcji z prośbą (czy teżżądaniem ${ }^{31}$ ), by tego typu wyjaśnienie pojawiło się na łamach czasopisma.

Wiadomo, że teksty Korczaka, które powstawały w getcie, przepisywane były na maszynie - z manuskryptów sporządzonych piórem, a częściej ołówkiem - przez jego młodszych współpracowników ${ }^{32}$. Jest zatem możliwe, że już na tym etapie doszło do drobnych przesunięć w stosunku do oryginalnego materiału. Jednakże raczej niewielka objętość listu do redakcji „Gazety Żydowskiej” i bardzo zwarta, logiczna narracja skłaniają do przypuszczeń, iż zachowane zostały pierwotne forma i treść. Co więcej, wydaje się raczej mało prawdopodobne, by Korczak nie przeczytał swojego listu przed sygnowaniem go używanym przez siebie nazwiskiem i prze-

27 Nie wiadomo dokładnie, o jakim pomniku Korczak mówi. Zarówno na cmentarzu Père Lachaise, jak i w nekropolii Montparnasse znajdują się bowiem poświęcone zmarłym nagrobki, których inskrypcje treściowo nieco przypominają tę przywołaną przez niego. Wydaje się jednak, że pisząc „piękny pomnik” miał on na myśli dzieło A. Bartholomé odsłonięte na Père Lachaise w 1899 roku, które mógł zobaczyć podczas swojej wizyty w stolicy Francji w 1910 roku. Monument ten upamiętnia nieznane ofiary oblężenia Paryża przez armię niemiecką (1870-1871) i chyba - per analogiam do sytuacji mieszkańców warszawskiego getta - z tego powodu wydał się Korczakowi godny przywołania. „Gazeta Żydowska” 1942, nr 3, z 7 I, s. 2.

29 Ibidem. Warto zwrócić uwagę na zarobkowy charakter przedsięwzięcia.

30 Nie da się ustalić, czy list wysłano, zaniesiono, czy podyktowano telefonicznie. Redakcja wydawanej w Krakowie „Gazety Żydowskiej” miała swoją filię w Warszawie przy ul. Elektoralnej 4, na pierwszym piętrze. $Z$ pracownikami można było skontaktować się również dzwoniąc pod numer telefonu 2-78-14.

31 W innym wojennym tekście J. Korczak (Do Biura Personalnego Rady Żydowskiej. Podanie. W: Pamiętnik i inne pisma z getta, s. 159) nazywa samego siebie „impetykiem”, co może wskazywać, że łatwo było wyprowadzić go $z$ równowagi.

32 W przypadku Pamiętnika zajmował się tym Henryk Azrylewicz, zatrudniony w kancelarii Domu Sierot. 
kazaniem dalej, sądzę nawet, że w przypadku błędów lub niedopuszczalnych przekłamań, list zostałby skopiowany po raz wtóry. Następnie redakcja „Gazety Żydowskiej”, otrzymawszy tego rodzaju materiał, mogła - czego nie jesteśmy już dziś w stanie w żaden sposób sprawdzić - dokonać na nim jakichś drobnych zmian, chociażby czysto edytorskich. Byłaby to zatem kolejna okazja, by oryginalny tekst listu Korczaka uległ jakimś niewielkim deformacjom.

Omawiany tekst wydrukowano na stronicy drugiej, w części przeznaczonej na wiadomości z Warszawy. Warto przyjrzeć się kontekstowi informacyjnemu, w którym się znalazł. W najbliższym sąsiedztwie sprostowania Korczaka umieszczono dość obszerny artykuł poświęcony polepszającej się sytuacji sierot w warszawskim getcie, noszacy tytuł Opieka nad dzieckiem na drodze rozwoju. Trzy nowe, wielkie Domy Sierot. Zaraz pod nim widnieje krótka notatka o kartach przemysłowo-patentowych, niżej zaś jeszcze - o ostatnich przedstawieniach teatralnych, które przygotowano w getcie. W dolnej części kolumny znajdują się informacje ogólne dotyczące całego Generalnego Gubernatorstwa. Biorąc pod uwagę fakt, że stronica pierwsza „Gazety Żydowskiej” miała charakter jawnie i bezsprzecznie polityczno-propagandowy, można przyjąć, że ci, którzy w ogóle kupowali i czytali to czasopismo, zaczynali lekturę od stronic kolejnych, poświęconych sprawom lokalnym. Stąd też takie umieszczenie listu Korczaka stwarzało szansę dotarcia do większej liczby odbiorców.

Mając świadomość licznych komplikacji, które mogły pojawić się na drodze od napisania listu do jego wydrukowania, oraz nakreśliwszy miejsce i czas, w którym się on ukazał, chciałabym przejść do analizy dostępnego tekstu. Początkowy zwrot honoryfikatywny Korczak kieruje nie do autorki (choć podpisała ona swój tekst imieniem i nazwiskiem), ale do redaktora naczelnego gazety, którego, być może, czyni odpowiedzialnym za wydrukowanie - w jego odczuciu - niefortunnego reportażu. Zaczyna w sposób umiarkowany, dziękując uprzejmie za życzliwość wobec placówki zarządzanej przez niego. Od razu jednak, niejako łagodząc cytatem z Arystotelesa to, co chce powiedzieć, przechodzi do prostowania informacji przedstawionych przez Ejzencwajg. Bardzo wyraźnie i jednoznacznie podkreśla, że Dom Sierot w żadnym momencie swojego funkcjonowania nie był dziełem tylko jednej osoby. Sprawiedliwie oceniając własne, skromne możliwości, Korczak pisze o szeroko zakrojonych zadaniach placówki wychowawczej, na czele której przyszło mu stanąć. Zadania te odpowiadają systematycznym działaniom, praktykowanym w Domu Sierot od samego początku jego istnienia, zatem: dobór dzieci, ich ubranie i łączacy się z tym opierunek, stworzenie $z$ nich wspólnoty za pomoca demokratycznie wypracowanych zasad ${ }^{33}$, codzienne wyżywienie, ogrzanie w czasie zimowych miesięcy, otoczenie opieką zastępcza, a także przygotowanie do dalszego życia, już poza murami placówki. Każde $z$ tych siedmiu zadań wymagałoby oddzielnego komentarza, aczkolwiek zebrane tutaj stanowią esencję tego, co Dom Sierot chciał zapewnić swoim podopiecznym, również - a może nawet przede wszystkim - w trud-

Zob. J. Ko r c zak, Jak kochać dziecko. Dom Sierot. W: Jak kochać dziecko. - Momenty wychowawcze. - Prawo dziecka do szacunku. Red. nauk. S. W oł o s zy n. Oprac. tekstów, geneza utworów, uwagi o tekstach E. Ci chy. Warszawa 1993. Dzieła. T. 7. 
nych czasach wojennych. Korczak nie przypisuje zasług sobie - i niewątpliwie widoczny sukces Domu Sierot ukazuje niejako w dwóch perspektywach: historycznej, gdy wspomina zbiorowy, systematyczny i długotrwały wysiłek ludzi dobrej woli, mniej lub bardziej zaangażowanych w działania Towarzystwa „Pomoc dla Sierot” (poprzez pracę, pomoc, radę, doświadczenie), wysiłek, który złożył się na kapitał, teraz wykorzystywany; w perspektywie hic et nunc zaś, kiedy to mówi o ludziach aktualnie wspierających Dom Sierot czy też bezpośrednio w nim zatrudnionych. Bez szczegółów, bardzo ogólnie wspomina także liczne zastępy dobroczyńców i społeczników znanych przedwojennej żydowskiej Warszawie, ale podkreśla również doniosłą rolę wszystkich bezimiennych, którzy poza działalnością charytatywną na rzecz tej placówki nie zapisali się w historii szczególnie wyraźnie. Dom Sierot nie jest w świetle listu niczym innym jak tylko efektywnie działającym (bogatym!) przedsiębiorstwem, instytucją, która przez lata wytrwale pracowała na zgromadzony przez siebie kapitał, rozumiany zresztą nie tylko jako dobra materialne. Korczak, wymieniając konkretne nazwiska osób zatrudnionych w Domu Sierot ${ }^{34}$, nazywa ich urzędnikami i administratorami, po prostu odpowiedzialnie wykonującymi powierzone im funkcje, jakie wynikaja $z$ cywilno-prawnych umów, zawartych $z$ instytucją prowadzącą placówkę, tym samym - ze społeczeństwem.

Na aktualne położenie Domu Sierot (jego „debet i credit”), które w malowniczy i chyba nie dość rzetelny sposób - przynajmniej w odczuciu Korczaka - oddała autorka reportażu, składa się również całościowy kontekst społeczno-polityczny, w jakim zakładowi przyszło się znaleźć, czyli, jak pisze autor listu, „walory i braki dzielnicy żydowskiej”. Co więcej, współodpowiedzialnymi za sytuację Domu Sierot czyni Korczak wszystkich mieszkańców getta, co, z jednej strony, odbiera mu laur zwycięstwa nad rzeczywistością dzielnicy żydowskiej, z drugiej zaś - przenosi na innych członków społeczeństwa świadomość konieczności opieki nad dzieckiem opuszczonym.

Do grona osób, którym Dom Sierot zawdzięcza swoją doskonałą opinię, Korczak zalicza nie tylko jego pracowników, ale przede wszystkim byłych i obecnych podopiecznych, którzy świadczą o jakości wychowania wdrażanego w życie w tej placówce. Wie, że życzliwość, zaufanie społeczne (czyli wspomniany wcześniej „credit”) i pozytywny wizerunek zakładu to efekt wieloletniego, wspólnego wysiłku, którego rezultaty widoczne sa w postępowaniu dzieci, i to nie tylko w trakcie ich przebywania w Domu Sierot, lecz także po latach od jego opuszczenia. Nie wprost wskazuje również na fakt, że nie wszyscy wychowankowie podtrzymują kontakt $z$ instytucją; zakłada jednak, iż nawet ci „najdalsi sercu i pamięci” są, mimo ich milczenia, dobrą reklamą instytucji, w której niegdyś przyszło im spędzić siedem lat młodzieńczych.

Na koniec listu Korczak usprawiedliwia sprostowanie podane przez siebie do druku. Jest bowiem zdania, że opublikowany wcześniej materiał podnosił w niewłaściwy sposób problem natury ogólnej, a mianowicie kwestię błędnego przypisywania „Zakresu, techniki, sprawności i wyniku pracy” osobom, którym została ona jedynie „powierzona do wykonania”. W tym miejscu warto chyba zwrócić uwagę na

34 Korczak wspomina tu Stefanię Wilczyńską, czyli swą bezpośrednią zastępczynię, zarządzającą Domem Sierot, oraz Natalię Poz, byłą wychowankę, prowadzącą tamtejszą kancelarię. 
wyjątkowo analityczne podejście Korczaka do sprawy organizacji - nie tylko opieki nad dzieckiem, zresztą. Dzieląc pracę na cztery komponenty (zakres, technika, sprawność, wynik), nawiązuje on do założeń prakseologii, czyli nauki, której przedmiotem jest przede wszystkim świadome i celowe działanie, oceniane pod względem skuteczności. W podaniu do Rady Żydowskiej w 1942 roku, przygotowanym na okoliczność czasowego zatrudnienia w Głównym Domu Schronienia przy ul. Dzielnej 39, Korczak pisze o sobie: „Jestem mistrzem w ekonomii wysiłku: jak Harpagon cedzę celowość każdej zużytej jednostki energii”" ${ }^{35}$, podkreślając tym samym zasadę, którą kierował się w dotychczasowych działaniach i którą próbował wszczepić swoim współpracownikom.

List sygnowany jest tylko inicjałem imienia i nazwiskiem pochodzaccymi z pseudonimu literackiego, którego Henryk Goldszmit używał na równi $z$ danymi osobowymi $z$ dokumentów urzędowych. Pod podpisem autora znajduje się jeszcze jego post scriptum, dotyczace planowanej przez Patronat Domu Sierot uroczystości, nabożeństwa poświęconego duszom „zmarłych Przyjaciół i Wychowanków Domu Sierot”. Warto zwrócić uwagę na zapis wielką literą, grzecznościowo wyróżniający zarówno dobroczyńców, jak i podopiecznych instytucji.

Bezpośrednio pod listem znajduje się ogłoszenie - najprawdopodobniej już nie jego autorstwa, aczkolwiek, być może, zamieszczone tu z jego inicjatywy, chociażby w ramach zadośćuczynienia za wydrukowanie reportażu nie do końca mile widzianego przez Korczaka, dotyczące atrakcji przygotowywanych dla dzieci i rodziców. W najbliższą sobotę po ukazaniu się listu Korczaka, 10 I, planowane było w Domu Sierot przedstawienie, którego głównym aktorem-opowiadaczem miał być sam dyrektor. W programie przewidziane są także elementy teatru kukiełek, animowanych przez podopiecznych i/lub wychowawców. Bilet wstępu - w tej samej cenie dla dzieci i dorosłych - kosztować miał 2 zł, co było równowartością 10 numerów "Gazety Żydowskiej”.

Ostatni znany tekst Korczaka opublikowany za jego życia jest bardzo spójny, przygotowany został ze ściśle określonego powodu, w sprecyzowanym celu i dla dokładnie wskazanego adresata. Powstał również w bardzo konkretnym kontekście społecznym i w dość specyficznej, niezupełnie klarownej sytuacji komunikacyjnej. Wraz z nieco późniejszym, wydanym dopiero pośmiertnie, Pamiętnikiem i innymi materiałami pisanymi w warszawskim getcie ${ }^{36}$ stanowi interesujący korpus różnorodnych źródeł dokumentujących życie i pracę instytucji wychowawczej w obliczu sytuacji kryzysowej.

Tekst ten jest też niewątpliwie namacalnym dowodem potwierdzającym uczciwość Korczaka: wobec współpracowników, wobec fundatorów, organizacji samopomocowych i osób prywatnych subsydiujących placówkę, wobec dzieci, wobec społeczeństwa, a przede wszystkim wobec samego siebie. Kwestia ta musiała mieć dla niego znaczenie fundamentalne, skoro wydało mu się zasadne i celowe, by umieścić swój list w niemieckiej „gadzinówce”. 


\section{Abstract \\ AGNIESZKA WITKOWSKA-KRYCH University of Warsaw \\ JANUSZ KORCZAK'S LAST TEXT PUBLISHED IN HIS LIFETIME}

The article presents and analyses Janusz Korczak's last text published in his lifetime. The material in question is a short letter to the editor of "Gazeta Żydowska" ("Jewish Gazette"), the newspaper sanctioned by the German authorities and directed to the inhabitants of ghettos of the General Government, written by Korczak as an answer to the previous Guta Ejzencwajg's panegyric report on the functioning of The Orphans' Home directed by Korczak. Referring to not fully confirmed data and statements, Korczak depicts the orphanage as a "common work," giving also an insight into how it worked in the last months of the war when ghetto still existed. The text, being both private (as a letter) and public (as an accessible press démenti), is an interesting complement to Korczak's private notes written in the walls of the capital city's Jewish closed quarter. 